\title{
Are Hummingbirds Facultatively Ammonotelic? Nitrogen Excretion and Requirements as a Function of Body Size
}

\author{
Todd J. McWhorter ${ }^{1, \star}$ \\ Donald R. Powers ${ }^{2}$ \\ Carlos Martínez del Rio ${ }^{3}$ \\ ${ }^{1}$ Department of Ecology and Evolutionary Biology, University \\ of Arizona, Tucson, Arizona 85721; ${ }^{2}$ Department of Biology, \\ George Fox University, Newberg, Oregon 97132; \\ ${ }^{3}$ Department of Zoology and Physiology, University of \\ Wyoming, Laramie, Wyoming 82071
}

Accepted 4/30/03

\begin{abstract}
Most birds are uricotelic. An exception to this rule may be nectar-feeding birds, which excrete significant amounts of ammonia under certain conditions. Although ammonia is toxic, because it is highly water soluble its excretion may be facilitated in animals that ingest and excrete large amounts of water. Birdpollinated plants secrete carbohydrate- and water-rich floral nectars that contain exceedingly little protein. Thus, nectarfeeding birds are faced with the dual challenge of meeting nitrogen requirements while disposing of large amounts of water. The peculiar diet of nectar-feeding birds suggests two hypotheses: (1) these birds must have low protein requirements, and (2) when they ingest large quantities of water their primary nitrogen excretion product may be ammonia. To test these hypotheses, we measured maintenance nitrogen requirements (MNR) and total endogenous nitrogen losses (TENL) in three hummingbird species (Archilochus alexandri, Eugenes fulgens, and Lampornis clemenciae) fed on diets with varying sugar, protein, and water content. We also quantified the form in which the by-products of nitrogen metabolism were excreted. The MNR and TENL of the hummingbirds examined were exceptionally low. However, no birds excreted more than $50 \%$ of nitrogen as ammonia or more nitrogen as ammonia than urates. Furthermore, ammonia excretion was not influenced by either water or protein intake. The smallest species (A. alexandri) excreted a significantly greater proportion $(>25 \%)$ of their nitrogenous wastes as ammonia than the larger hum-
\end{abstract}

${ }^{\star}$ Corresponding author. Present address: Department of Wildlife Ecology, University of Wisconsin, Madison, Wisconsin 53706; e-mail: tjmcwhorter@wisc.edu.

Physiological and Biochemical Zoology 76(5):731-743. 2003. (C) 2003 by The University of Chicago. All rights reserved. 1522-2152/2003/7605-2151\$15.00 mingbirds $(\approx 4 \%)$. Our results support the hypothesis that nectar-feeding birds have low protein requirements but cast doubt on the notion that they are facultatively ammonotelic. Our data also hint at a possible size-dependent dichotomy in hummingbirds, with higher ammonia excretion in smaller species. Differences in proportionate water loads and/or postrenal modification of urine may explain this dichotomy.

\section{Introduction}

Birds are generally believed to be uricotelic under all circumstances (e.g., Schmidt-Nielsen 1990; Goldstein and Skadhauge 2000). Uricotelic animals are those that excrete more than $50 \%$ of their nitrogenous wastes as uric acid and its salts (which we will hereafter refer to as urates). Urates are relatively nontoxic, have low solubility in water, and can be held in colloid solutions with proteins at very high concentrations (Janes and Braun 1997). Although urates are energetically expensive to synthesize, they may be favored as nitrogenous waste products in desiccating environments and in animals with cleidoic eggs because they can be excreted with little water (Willmer et al. 2000). Birds are terrestrial and often need to save water, but some bird species can ingest and excrete prodigious volumes of water. Hummingbirds consuming dilute nectars, for example, can ingest up to six times their body mass per day and can show water fluxes similar to those of amphibians and freshwater fish (Beuchat et al. 1990; McWhorter and Martínez del Rio 1999; Martínez del Rio et al. 2001). Until relatively recently, nitrogen excretion had not been examined in birds with high rates of water flux.

Preest and Beuchat (1997) exposed Anna's hummingbirds (Calypte anna) to low air temperatures $\left(10^{\circ} \mathrm{C}\right)$. Birds increased their rates of food and water intake when faced with increased metabolic (i.e., thermoregulatory) demands. Surprisingly, about half of the birds exposed to $10^{\circ} \mathrm{C}$ became ammonotelic (Preest and Beuchat 1997). These results are exceptionally significant because (1) ammonia excretion is believed to occur only as a by-product of the regulation of acid-base balance in birds (e.g., King and Goldstein 1985), and (2) they suggest that hummingbirds are "facultatively" ammonotelic. Facultatively ammonotelic animals excrete primarily urates but switch to ammonia under certain conditions (McNab 2002 and references therein). Like uric acid and urea, ammonia is a by-product of amino acid metabolism. Unlike uric acid and urea, however, 
ammonia does not require additional energy to be synthesized, but it is highly toxic and highly soluble in water (Wright 1995). Preest and Beuchat (1997) speculated that hummingbirds could reduce the metabolic cost of nitrogen excretion by excreting primarily ammonia under conditions of high water flux. Facultative ammonotely can also be advantageous because it reduces the potential loss of proteins and cations associated with urate excretion (McNabb et al. 1973; Laverty and Wideman 1989; Dawson et al. 1991; Janes and Braun 1997). When nectarfeeding birds are water limited by either high temperatures or highly concentrated floral nectars, they could shift back to uricotely (Calder and Hiebert 1983; Preest and Beuchat 1997).

Roxburgh and Pinshow (2002) examined the effects of water, electrolyte and protein intake, and ambient temperature on nitrogen excretion by nectarivorous Palestine sunbirds ( $\mathrm{Nec}$ tarinia osea). They found that the proportion of ammonia in ureteral urine and excreted fluid was independent of water and salt ingestion but decreased in excreted fluid with increased protein intake. They hypothesized that the ammonotely observed in Palestine sunbirds was "apparent," simply the result of decreasing urate excretion in animals feeding on low-protein diets. Therefore, currently available data leave the question of ammonotely in nectar-feeding birds somewhat unanswered. Is facultative, true ammonotely found in hummingbirds but not in sunbirds? Roxburgh and Pinshow's (2002) study makes a significant point: protein intake may affect the form in which nitrogen is excreted by birds. Nectar-feeding birds are unusual because they can ingest large amounts of water and also because they appear to have low protein intakes and requirements.

Floral nectar diets present animals with a unique set of physiological challenges. Bird-pollinated plants secrete carbohydrate-rich nectar with low nitrogen content (Baker and Baker 1982; Gottsberger et al. 1984). Under many circumstances, nectar-feeding birds must consume large volumes of excess water to meet their metabolic demands (Beuchat et al. 1990; Lotz and Nicolson 1999; McWhorter and Martínez del Rio 1999; Martínez del Rio et al. 2001; Nicolson and Fleming 2003). The mechanics of carbohydrate digestion and gut function, and how these processes affect feeding behavior, are relatively well understood in nectar-feeding birds (Karasov et al. 1986; Martínez del Rio 1990; McWhorter and Martínez del Rio 1999, 2000; Martínez del Rio et al. 2001). Until recently (Roxburgh and Pinshow 2000; van Tets and Nicolson 2000), the nitrogen requirements of nectarivorous birds received little attention aside from the pioneering studies of Paton (1982) and Brice and Grau (Brice and Grau 1989, 1991; Brice 1992). The low protein and amino acid levels in floral nectars are believed to be insufficient to meet the nutritional needs of nectarivores (Baker 1977; Baker and Baker 1977; Brice and Grau 1991; Law 1992; Martínez del Rio 1994; Roxburgh and Pinshow 2000; van Tets and Nicolson 2000), although nectar-feeding birds also consume arthropods (Wagner 1946; Paton 1982; Brice and Grau 1991; Brice 1992; van Tets and Nicolson 2000). Because they appear to obtain the majority of their energy from floral nectars, however, the protein requirements of these animals are predicted to be extremely low.

Nitrogen requirements have been measured in a handful of representatives of each of the three major radiations of nectarfeeding birds. To date, one species of honeyeater (Meliphagidae; Paton 1982), one species of hummingbird (Trochilidae; Brice and Grau 1991), and two species of sunbirds (Nectariniidae; Roxburgh and Pinshow 2000; van Tets and Nicolson 2000) have been examined. The nitrogen requirements and endogenous nitrogen losses of nectar-feeding birds appear to be only a fraction of the value predicted for birds on the basis of body mass (Robbins 1993; Roxburgh and Pinshow 2000). This result is not unexpected on both evolutionary and physiological grounds. There is an evolutionary necessity to minimize nitrogen loss when specializing on low-nitrogen foods, and a liquid fiber- and lipid-free nectar diet may reduce fecal nitrogen losses (Robbins 1993).

In this study, we attempted to integrate the insights of Preest and Beuchat (1997) with those of Roxburgh and Pinshow (2002). We manipulated both water and protein intake in captive hummingbirds to test two complementary hypotheses: (1) hummingbirds have low protein requirements, and (2) when ingesting high water loads they increase the fraction of total nitrogen that is excreted as ammonia. We tested our hypotheses under natural ambient conditions using captive individuals of three hummingbird species that are locally sympatric in southeastern Arizona: the magnificent hummingbird (Eugenes fulgens Gould), the blue-throated hummingbird (Lampornis clemenciae Swainson), and the black-chinned hummingbird (Archilochus alexandri Bourcier and Mulsant). Our experiments took advantage of the behavioral response of nectar-feeding birds to varying energy density in food (López-Calleja et al. 1997; McWhorter and Martínez del Rio 1999; McWhorter and LópezCalleja 2000; McWhorter and Martínez del Rio 2000; Martínez del Rio et al. 2001). By varying both sugar and protein concentration in food, we were able to elicit a wide range of water and nitrogen intakes while maintaining constant energy intake. We measured the maintenance nitrogen requirements (MNR) and total endogenous nitrogen losses (TENL) in these hummingbirds and also quantified the forms in which their nitrogenous wastes were excreted.

\section{Material and Methods}

Adult male hummingbirds (Eugenes fulgens $7.51 \pm 0.45 \mathrm{~g}$, $n=7$; Lampornis clemenciae $7.91 \pm 0.41 \mathrm{~g}, n=7$; Archilochus alexandri $2.66 \pm 0.05 \mathrm{~g}, n=7$, mean body mass $[\mathrm{Mb}] \pm \mathrm{SD}$ ) were captured with mist nets on the grounds of the American Museum of Natural History's Southwestern Research Station in Portal, Arizona, during June and July of 1999 and housed individually in wire mesh cages $(40 \mathrm{~cm} \times 25 \mathrm{~cm} \times 30 \mathrm{~cm})$ inside an outdoor aviary. The study was conducted under 
natural ambient temperature and light cycles (photoperiod approximately $15 \mathrm{~L}: 9 \mathrm{D}$, maximum temperature averaged $31.14^{\circ} \pm 2.56^{\circ} \mathrm{C}$, minimum temperature averaged $13.12^{\circ} \pm$ $2.7^{\circ} \mathrm{C}$ ). Birds were allowed to acclimate to experimental cages and diets for 24-48 h before the experiments began. This short acclimation period was deemed appropriate for two reasons: (1) food intake by hummingbirds stabilized within $2 \mathrm{~h}$ of feeding experimental diets, and (2) examination of excreta confirmed that all traces of arthropod matter had cleared the digestive tract by $24 \mathrm{~h}$ postcapture. During experiments, birds were fed synthetic diets modified from those reported in Brice and Grau (1989). Diets contained only sucrose, $\mathrm{NaCl}$, and casein acid hydrolysate as a nitrogen source (contains all 20 common amino acids; Sigma Chemical, St. Louis, Mo.). Six different diets were used to obtain a wide range of food and, thus, water and nitrogen intake rates (Fig. 1). Sucrose concentration ranged from 0.292 to $1.168 \mathrm{~mol} \mathrm{~L}^{-1}$ with three nitrogen levels $(0,1.2$, and $4.0 \mathrm{~g} \mathrm{~L}^{-1}$ casein acid hydrolysate). $\mathrm{NaCl}$ concentration was held constant at $9.07 \mathrm{mmol} \mathrm{L} \mathrm{m}^{-1}$.

Individual birds were randomly assigned to a diet, so that each species was tested on each diet at least once. At 0800 hours on the day of the experiment, a galvanized metal pan containing $200 \mathrm{~mL}$ of mineral oil was placed under the cage to collect excreta (mixed urinary and fecal materials) without allowing for evaporation. Birds were then left undisturbed for $24 \mathrm{~h}$. Food was available ad lib., and intake was measured using a small calibrated glass feeding tube placed through a hole in the wall of the experimental cage. Body mass was measured upon capture and before release and remained constant (or increased slightly in the case of $A$. alexandri) over the experimental period. Excreta and mineral oil were collected after $24 \mathrm{~h}$, put in Nalgene bottles, and frozen at $-20^{\circ} \mathrm{C}$ for later analysis. Birds were held for a maximum of $3 \mathrm{~d}$ (including acclimation and experimental periods) and subsequently released unharmed at the site of capture.

Excreta samples were thawed, separated from the mineral oil by centrifuging at 5,000 rpm for $3 \mathrm{~min}$, and diluted with 1,000 $\mathrm{mL}$ of distilled water to provide adequate volumes for analysis. One hundred microliters $(100 \mu \mathrm{L})$ of $10 \%$ (vol/vol) acetic acid was added to acidify samples and thus prevent the volatilization of ammonia. The $\mathrm{pH}$ of samples after the addition of acid ranged from 3.75 to 5.48. Excreta and food samples were analyzed for total nitrogen content in a Carlo Erba NA 1500 elemental analyzer (CE Instruments, Milan) at the Columbia University Biosphere 2 stable isotope facility in Oracle, Arizona. Liquid samples $(15 \mu \mathrm{L})$ were pipetted into precleaned tin capsules containing $10 \mathrm{mg}$ of acid-washed Chromasorb W adsorbent (Costech, Valencia, Calif.). Benzoic acid was used as a standard for the elemental analysis. Nitrogen balance requirements and endogenous losses were determined by regression of apparent nitrogen retention (nitrogen intake minus excretion) on nitrogen intake (Smith and Green 1987; Brice and Grau 1991; Korine et al. 1996; Witmer 1998; Delorme and
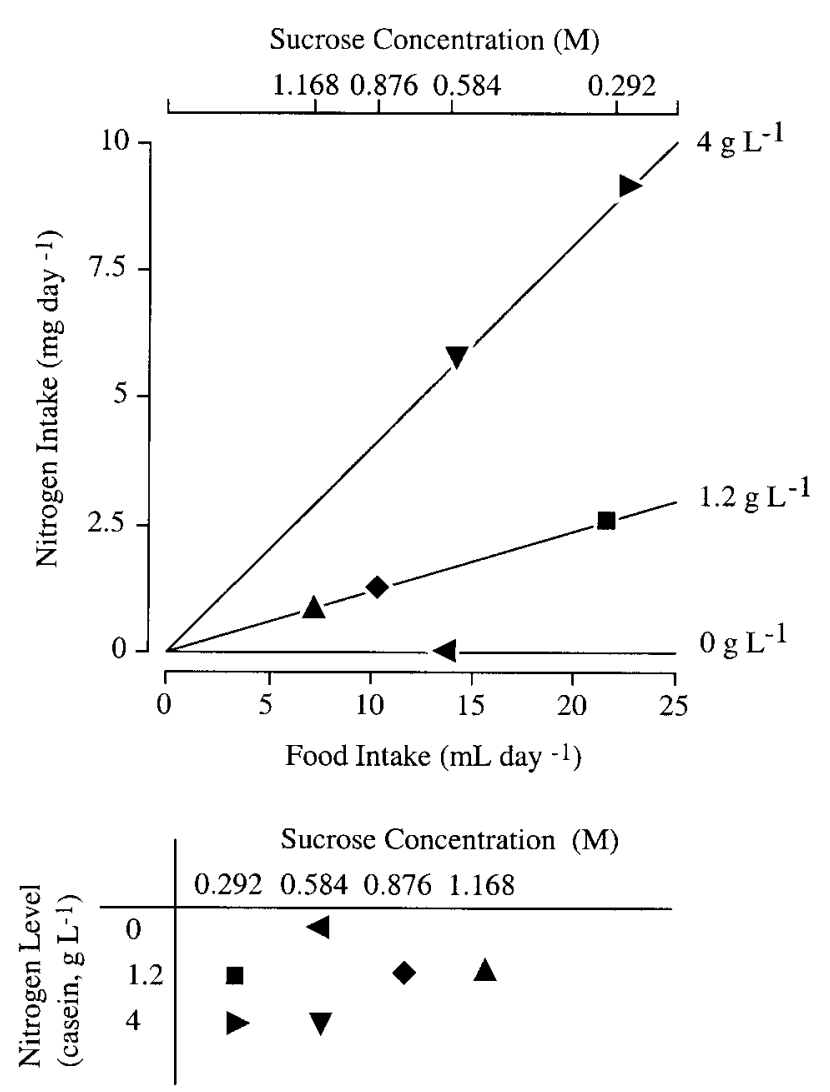

Figure 1. Hummingbirds vary food intake when fed solutions of different sugar concentrations. When fed low sucrose concentrations $\left(0.292 \mathrm{~mol} \mathrm{~L}^{-1}\right)$ they drink significantly more than when fed high concentrations $\left(1.168 \mathrm{~mol} \mathrm{~L}^{-1}\right)$. Note that the food intake and sugar concentration axes in the top panel run in opposite directions. We manipulated protein intake by varying both sugar and protein content of food. The table in the lower panel shows the combinations of sugar concentrations and nitrogen levels used in our experimental design. The lines in the upper panel show predicted nitrogen intake levels for a 7.6-g hummingbird feeding on each nitrogen level when sugar concentration is varied. Each symbol represents a unique combination of sucrose concentration and nitrogen level. We achieved high protein intakes by feeding hummingbirds on low-sucrose concentrations $\left(0.292\right.$ and $\left.0.584 \mathrm{~mol} \mathrm{~L}^{-1}\right)$ with high-protein contents $(1.2$ and $4 \mathrm{~g}$ $\left.\mathrm{L}^{-1}\right)$. Conversely, we achieved low-protein intakes by feeding hummingbirds on high-sucrose concentrations $\left(0.876\right.$ and $\left.1.168 \mathrm{~mol} \mathrm{~L}^{-1}\right)$ and low-nitrogen contents $\left(0\right.$ and $\left.1.2 \mathrm{~g} \mathrm{~L}^{-1}\right)$. Because hummingbirds modulate volumetric intake to maintain constant sugar intake, we were able to manipulate nitrogen intake with minimal changes in energy consumption.

Thomas 1999; van Tets and Hulbert 1999; Roxburgh and Pinshow 2000) using total nitrogen data from the elemental analysis (Fig. 3).

Clinical diagnostic kits (Sigma Chemical, St. Louis, Mo.) were used to analyze excreta samples for uric acid (procedure 685), urea (procedure 535), ammonia (procedure 171-UV), creatinine (procedure 555), creatine (modification using pro- 
cedure 520 without creatine kinase substrate), and bile acids (procedure 450, assuming an equal mix of cholic, deoxycholic, and lithocholic acids [mean molecular weight (MW) = $392.58 \mathrm{~g} \mathrm{~mol}^{-1}$ ] and that each bile acid is bound to either taurine or glycine [mean $\mathrm{MW}=100.095 \mathrm{~g} \mathrm{~mol}^{-1}$, mean $14.925 \% \mathrm{~N}]$ ). Before analysis for uric acid content, an aliquot of each excreta sample was diluted 2:1 with a $1.0 \mathrm{~mol} \mathrm{~L} \mathrm{~L}^{-1}$ $\mathrm{LiOH}$ solution to dissolve urate precipitates (Laverty and Wideman 1989; Roxburgh and Pinshow 2002). Samples were also analyzed for total soluble protein using the Bio-Rad Protein Assay Kit II (Bradford method, catalog 500-0002, Bio-Rad Laboratories, Hercules, Calif.). Nitrogen excretion in each of these forms is reported as a percentage of the total excreted nitrogen measured using these biochemical assays. Osmolarity of excreta supernatant was measured using a Wescor model 5500 vapor pressure osmometer (Wescor, Logan, Utah).

\section{Statistical Analysis}

In order to compare the relationship of volumetric intake and food energy density among the three species, we used ANCOVA. ANCOVA was performed on log-transformed data because we found that the relationship between intake and food energy density was best described by a power function (Martínez del Rio et al. 2001). ANCOVA was also used to probe for differences in the slopes and intercepts of nitrogen retention curves among species. ANOVA was used to test for differences in mean nitrogen excreted as a given nitrogenous waste product between species, and least squares linear regression was used to test for correlations between excretion of all forms of nitrogenous wastes and water or nitrogen intake. Paired $t$-tests were used to determine the significance of body mass changes over the experimental period. Values are reported as means \pm SE, unless otherwise indicated, and significance was accepted at $\alpha=0.05$.

\section{Results}

\section{Food Intake: Energy and Nitrogen}

Volumetric food intake $\left(I, \mathrm{~mL} \mathrm{~d}^{-1}\right)$ by hummingbirds decreased significantly with increased sucrose concentration $\left(C\right.$, mol L $\mathrm{L}^{-1}$ ANCOVA $\left._{\text {concentration }} F_{1,17}=47.51, P<0.0001\right)$. The relationship between intake and concentration was best described by power functions in all species $\left(I=6.72[C]^{-0.78}, I=8.93[C]^{-0.76}\right.$, and $I=11.64[C]^{-0.71}, r^{2} \geq 0.83$, for Archilochus alexandri, Eugenes fulgens, and Lampornis clemenciae, respectively; Fig. 2). Archilochus alexandri ate less at any given sugar concentration than either of the larger species $\left(\right.$ ANCOVA $_{\text {species }} F_{2,17}=17.97, P=$ 0.002, Tukey's HSD $P<0.05$ for both species), but $E$. fulgens and $L$. clemenciae had statistically similar concentrationcorrected volumetric intake rates. There was no significant difference in the slopes of the intake response relationship among the three species $\left(\mathrm{ANCOVA}_{\text {slopes }} F_{2,15}=0.41, P=0.67\right)$. Sucrose
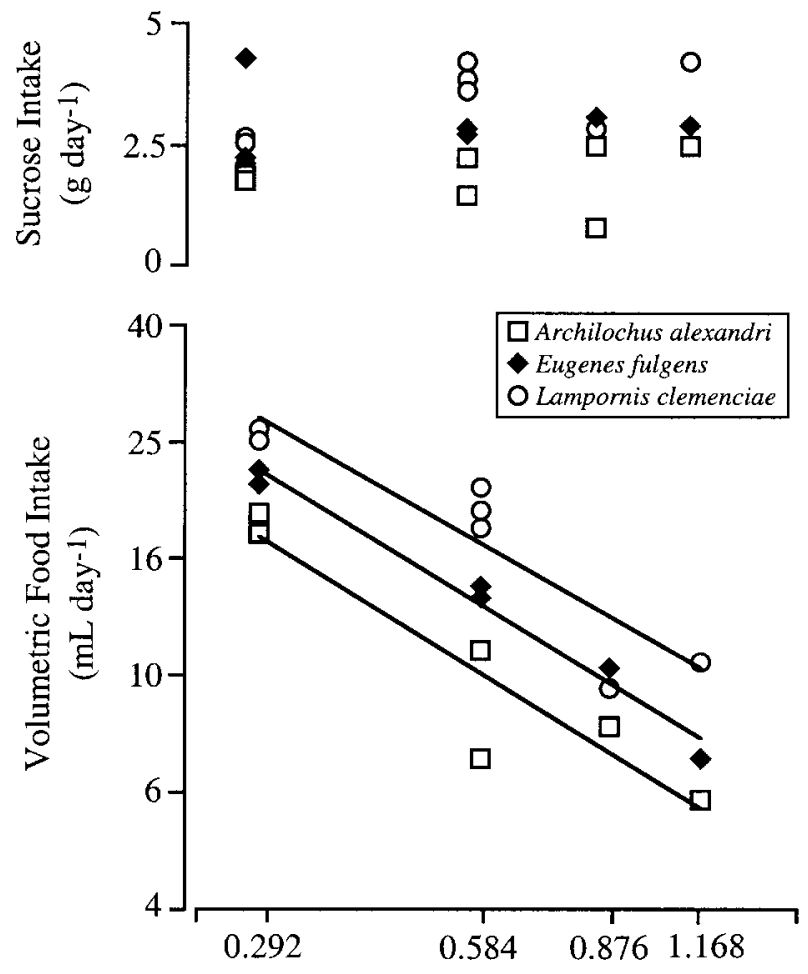

Sucrose Concentration in Diet $\left(\mathrm{mol} \mathrm{L}^{-1}\right)$

Figure 2. Volumetric food (bottom) and sucrose (top) intake as a function of sugar concentration in black-chinned hummingbirds (Archilochus alexandri), magnificent hummingbirds (Eugenes fulgens), and blue-throated hummingbirds (Lampornis clemenciae). Food intake (I) decreased significantly with increased sucrose concentration $(C)$ in relationships adequately described by power functions $(I=$ $6.72[C]^{-0.78}, I=8.93[C]^{-0.76}$, and $I=11.64[C]^{-0.71}, r^{2} \geq 0.83, n=7$ for each of the three species, respectively). Concentration-corrected volumetric intake by $A$. alexandri was significantly lower than that of both larger species. Note that the scales of both axes in the bottom panel are logarithmic and that intake has not been standardized by body mass. Sucrose intake per day did not vary with sucrose concentration but was significantly lower in A. alexandri.

intake $\left(\mathrm{g} \mathrm{d}^{-1}\right)$ did not vary significantly with food energy density (ANCOVA $_{\text {concentration }} F_{1,17}=0.66, P=0.43$ ) but was significantly lower in A. alexandri $\left(\mathrm{ANCOVA}_{\text {species }} F_{2,17}=8.98, P=0.002\right.$, Tukey's HSD $P<0.05$ for both larger species; Fig. 2). Daily sucrose intake averaged $2.06 \pm 0.17,2.68 \pm 0.16$, and $3.45 \pm$ $0.28 \mathrm{~g}$ (mean $\pm \mathrm{SE}$ ) for A. alexandri, E. fulgens, and L. clemenciae, respectively. Assuming $16.6 \mathrm{~kJ} \mathrm{~g}^{-1}$ of sucrose, this translates into relatively constant energy intake rates of $34.2 \pm 2.82,44.49 \pm 2.66$, and $57.27 \pm 4.65 \mathrm{~kJ} \mathrm{~d}^{-1}$ for the three species, respectively. At our experimental concentrations, nitrogen content did not have an effect on intake ANCOVA $_{\text {nitrogen }}$ $F_{1,16}=0.26, P=0.62$ when diet nitrogen level was added to the food intake model as a covariate).

When food intake rates were scaled to metabolic body mass 


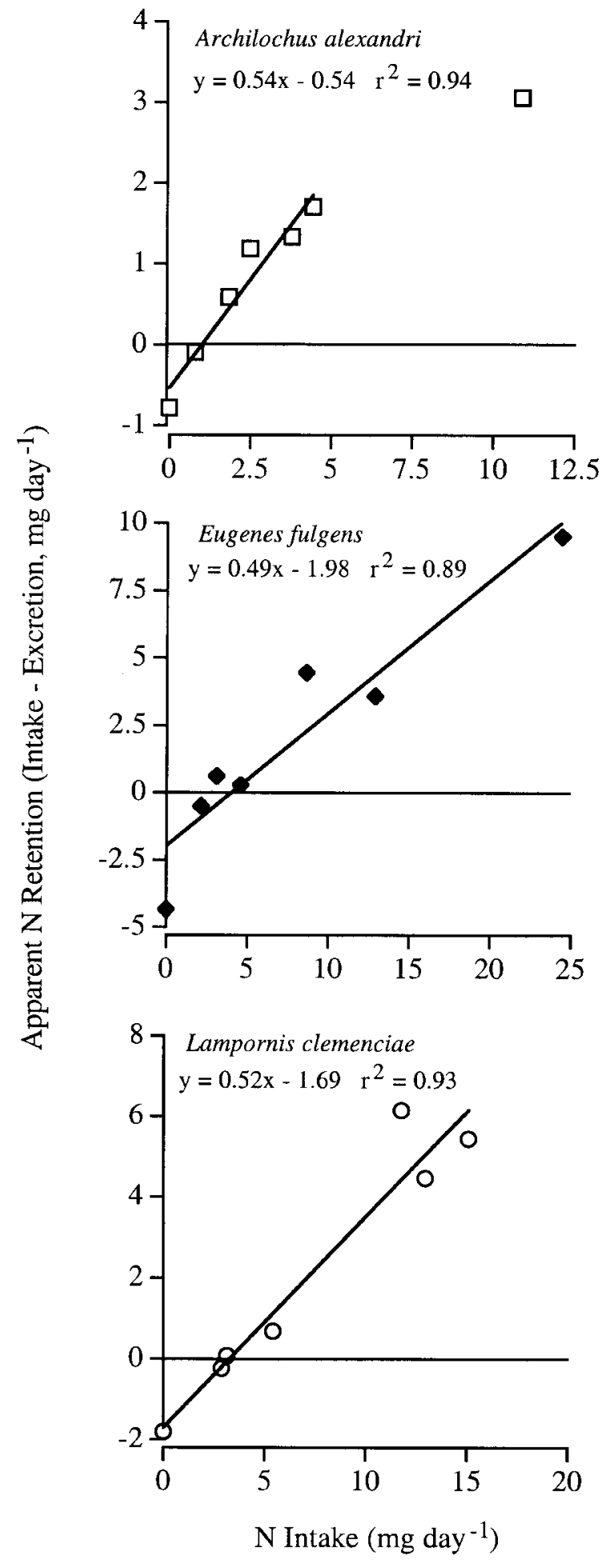

Figure 3. Apparent nitrogen retention increased significantly with nitrogen intake in all species. Maintenance nitrogen requirements (MNR) and total endogenous nitrogen losses (TENL) when feeding on a nitrogen-free diet were determined for each species using the $x$ - and $y$-intercepts of a least squares linear regression, respectively. In Archi- $\left(\mathrm{kg}^{0.75}\right)$ for interspecific comparisons (Robbins 1993), concentration-corrected volumetric intake by $A$. alexandri was significantly higher than that of the larger species, which did not differ from each other $\left(\mathrm{ANCOVA}_{\text {species }} F_{2,15}=17.08, P=0.0001\right.$, Tukey's HSD $P<0.05)$. Sucrose intake by $A$. alexandri was also significantly higher (one-way ANOVA $F_{2,16}=10.19, \quad P=$ 0.0014 , Tukey's HSD $P<0.05$ for both larger species). Metabolic mass corrected volumetric food and sucrose intake rates were about 1.5 times higher in $A$. alexandri than in the larger species.

Body mass remained constant $(t=0.17, \mathrm{df}=6, P=0.87$ for E. fulgens; $t=-0.57$, df $=6, P=0.59$ for $L$. clemenciae) or increased slightly (mean increase 9.72\% $\pm 2.47 \%, t=-3.81$, $\mathrm{df}=6, P=0.009$ for $A$. alexandri) over the experimental period. There was no significant correlation between percent body mass increase and apparent nitrogen retention in A. alexandri $\left(F_{1,6}=0.206, P=0.67\right)$.

\section{Nitrogen Balance}

Daily nitrogen intake ranged from 0 to $10.89 \mathrm{mg}$ in A. alexandri, 0 to $24.44 \mathrm{mg}$ in E. fulgens, and 0 to $15.09 \mathrm{mg}$ in L. clemenciae. Apparent nitrogen retention (intake minus excretion) increased significantly with nitrogen intake in all species $\left(\mathrm{ANCOVA}_{\text {nitrogen }}\right.$ $F_{1,16}=154.32, P<0.0001$; Fig. 3$)$. The slopes of these relationships were almost identical $\left(\approx 0.5, \mathrm{ANCOVA}_{\text {slopes }} F_{2,14}=0.06\right.$, $P=0.95)$. MNR and TENL were determined for each species using the $x$ - and $y$-intercepts of a least squares linear regression model, respectively (Smith and Green 1987; Brice and Grau 1991; Korine et al. 1996; Witmer 1998; Delorme and Thomas 1999; van Tets and Hulbert 1999; Roxburgh and Pinshow 2000). In $A$. alexandri, the relationship between apparent nitrogen retention and intake was nonlinear at high intakes. Thus, apparent nitrogen retention in A. alexandri was lower than expected at the highest observed nitrogen intake rate. We did not use this value for nitrogen balance calculations. MNR and TENL values are reported in Table 1.

\section{Nitrogen Excretion}

Hummingbirds excreted nitrogen in detectable quantities as ammonia, uric acid (urates), urea, soluble protein, creatine, creatinine, and associated with bile acids (i.e., as taurine and/ or glycine associated with cholic, deoxycholic, and lithocholic

lochus alexandri, the relationship between apparent nitrogen retention and intake was nonlinear at high intakes. Because apparent nitrogen retention in A. alexandri was lower than expected at the highest observed nitrogen intake rate, we did not use this value for balance calculations. The apparent retention observed at most intake rates can be easily explained by nonexcretory losses of skin cells and feather components. Birds maintained body mass throughout the $24-\mathrm{h}$ experimental period. Note that the scales of the axes in this figure differ among species. MNR and TENL values are reported in Table 1. 
Table 1: Maintenance nitrogen requirements (MNR) and total endogenous nitrogen losses (TENL) of nectar- and fruitfeeding vertebrates below $100 \mathrm{~g}$ in body mass

\begin{tabular}{|c|c|c|c|c|}
\hline Species & $\begin{array}{l}\text { Body } \\
\text { Mass } \\
\text { (g) }\end{array}$ & $\begin{array}{l}\text { MNR } \\
\mathrm{mg} \mathrm{N} \mathrm{kg}^{-0.75} \mathrm{~d}^{-1} \\
\left(\mathrm{mg} \mathrm{N} \mathrm{d}^{-1}\right)\end{array}$ & $\begin{array}{l}\text { TENL } \\
\mathrm{mg} \mathrm{N} \mathrm{kg}^{-0.75} \mathrm{~d}^{-1} \\
\left(\mathrm{mg} \mathrm{N} \mathrm{d}^{-1}\right)\end{array}$ & Source \\
\hline Black-chinned hummingbird (Archilochus alexandri) & 2.7 & $\begin{array}{l}85.5 \\
(1.01)\end{array}$ & $\begin{array}{l}46 \\
(.54)\end{array}$ & This study \\
\hline Broad-tailed hummingbird (Selasphorus platycercus) & 3.4 & $\begin{array}{l}62.6 \\
(.88)\end{array}$ & $\begin{array}{l}45.2 \\
(.64)\end{array}$ & McWhorter 1997 \\
\hline Costa’s hummingbird (Calypte costae) & 3.5 & $\begin{array}{c}77.1 \\
312.7^{\mathrm{a}}\end{array}$ & 77.8 & Brice and Grau 1991 \\
\hline Palestine sunbird (Nectarinia osea) & 6.9 & $\begin{array}{r}165 \\
213^{\mathrm{a}}\end{array}$ & 81 & Roxburgh and Pinshow 2000 \\
\hline Magnificent hummingbird (Eugenes fulgens) & 7.5 & $\begin{array}{l}158 \\
(4.03)\end{array}$ & $\begin{array}{l}77.7 \\
(1.98)\end{array}$ & This study \\
\hline Blue-throated hummingbird (Lampornis clemenciae) & 7.9 & $\begin{array}{c}122.4 \\
(3.24)\end{array}$ & $\begin{array}{l}63.8 \\
(1.69)\end{array}$ & This study \\
\hline Lesser double-collared sunbird (Nectarinia chalybea) & 8 & 253.2 & 157 & Van Tets and Nicolson 2000 \\
\hline Queensland blossom bat (Syconycteris australis) & 18 & 337 & 255.1 & Law 1992 \\
\hline New Holland honeyeater (Phylidonyris novaehollandiae) & 20 & 93.2 & 60.1 & Paton 1982 \\
\hline Eastern pygmy possum (Cercartetus nanus) & $\begin{array}{l}25.4^{\mathrm{b}} \\
30.9^{\mathrm{d}}\end{array}$ & $\begin{array}{r}40.9^{\mathrm{b}, \mathrm{c}} \\
149.3^{\mathrm{c}, \mathrm{d}}\end{array}$ & $\begin{array}{l}29.2^{\mathrm{b}} \\
62.6^{\mathrm{d}}\end{array}$ & Van Tets and Hulbert 1999 \\
\hline Cedar waxwing (Bombycilla cedrorum) & 34.5 & 264.3 & 68.5 & Witmer 1998 \\
\hline Phyllostomid fruit-bat (Artibeus jamaicensis) & 37 & $213.7^{\mathrm{c}}$ & 196.6 & Delorme and Thomas 1999 \\
\hline
\end{tabular}

Note. Values were estimated by regression of apparent $\mathrm{N}$ retention on $\mathrm{N}$ intake except as otherwise specified. Data are arranged in order of increasing body mass. Values in parentheses are $\mathrm{mg} \mathrm{N} \mathrm{d}^{-1}$.

${ }^{a}$ Minimum body mass maintenance requirement.

b Sugar plus pollen diet.

c Truly digestible nitrogen.

d Sugar plus mealworm diet.

acids; see "Material and Methods" for assumptions). Nitrogenous waste excretion by hummingbirds varied among species (Table 2). Archilochus alexandri excreted the largest proportion of assayed nitrogen as ammonia (ANOVA $F_{2,18}=61.35, P<$ 0.0001 , Tukey's HSD $P<0.05)$, but there were no significant differences in ammonia excretion between E. fulgens and $L$. clemenciae. Consequently, A. alexandri excreted a smaller proportion of assayed nitrogen as urates than either of the larger species (ANOVA $F_{2,18}=18.84, P<0.0001$, Tukey's HSD $P<$ $0.05)$, which again were not significantly different from each other. The mean proportion of nitrogen excreted in each other form was not significantly different among species. Excretion of nitrogen associated with bile acids was detectable in trace amounts for all species. No birds excreted $>50 \%$ of nitrogen as ammonia, or more nitrogen as ammonia than urates, during any experimental trial. Nitrogen excretion data are summarized in Table 2.

The proportion of assayed nitrogen excreted as ammonia did not increase with water intake rate as hypothesized in any species (Fig. 4). There was a significant negative correlation between ammonia excretion and water intake rate in $L$. clemenciae $\left(y=-0.16 x+5.74, r^{2}=0.67 ; F_{1,6}=10.16, P<0.03\right)$. In addition, there was a significant negative correlation between urea excretion and water intake rate in E. fulgens $(y=-0.17 x+$ $\left.6.4, r^{2}=0.89 ; F_{1,5}=31.79, P<0.005\right)$. There were no additional significant correlations between the proportion of nitrogen excreted in any other form and water intake rate for any species. Creatinine excretion was positively correlated with nitrogen intake rate in $A$. alexandri $\left(y=0.1 x-0.004, r^{2}=\right.$ $\left.0.59 ; F_{1,6}=7.15, P<0.05\right)$. There were no other significant correlations between the proportion of nitrogen excreted in any form and nitrogen intake rate for any species.

Excreta osmolality did not vary among species $\left(\right.$ ANCOVA $_{\text {species }}$ $F_{2,15}=0.06, P=0.94$ ANCOVA $\left._{\text {slopes }} F_{2,13}=1.81, P=0.2\right)$ but decreased significantly with increasing water intake rate in a nonlinear fashion $\left(y=12.93+[2241.66 / x], \quad r^{2}=0.73 ; \quad F_{1,18}=\right.$ 45.33, $P<0.0001$; Fig. 5). Osmolality ranged from 102 to 667.8 mOsm $\left(\mathrm{kg} \mathrm{H}_{2} \mathrm{O}\right)^{-1}$ for all species combined.

\section{Discussion}

As predicted, we found that all three hummingbird species had extraordinarily low nitrogen requirements. Contrary to our predictions, and in contrast with Preest and Beuchat's (1997) pre- 
Table 2: Nitrogen excretion by hummingbirds, reported as a percentage of the total excreted $\mathrm{N}$ measured using biochemical assays (mean $\pm \mathrm{SE})$.

\begin{tabular}{|c|c|c|c|c|c|c|c|}
\hline Species & Ammonia & Urates & Urea & Soluble Protein & Creatine & Creatinine & Bile Acids ${ }^{\mathrm{a}}$ \\
\hline \multicolumn{8}{|l|}{ Black-chinned hummingbird } \\
\hline (Archilochus alexandri) & $25.7 \pm 2.7^{\mathrm{b}}$ & $64.6 \pm 4.5^{b}$ & \pm .9 & \pm 1.4 & $1.3 \pm .3$ & $.4 \pm .2$ & $.031 \pm .012$ \\
\hline \multicolumn{8}{|l|}{ Magnificent hummingbird } \\
\hline (Eugenes fulgens) & $4.5 \pm$ & $84.6 \pm .9$ & $4.1 \pm .4$ & $4.7 \pm .9$ & $1.5 \pm .3$ & $.6 \pm .3$ & $.013 \pm .004$ \\
\hline \multicolumn{8}{|l|}{ Blue-throated hummingbird } \\
\hline (Lampornis clemenciae) & $3.1 \pm .5$ & $86.9 \pm 1.7$ & $4.2 \pm .8$ & $4.3 \pm .9$ & $1.1 \pm .1$ & $.3 \pm .2$ & $.011 \pm .004$ \\
\hline
\end{tabular}

a Nitrogen in taurine and/or glycine associated with cholic, deoxycholic, and lithocholic acids; see "Material and Methods" for assumptions.

b Significantly different from mean proportion of assayed N excreted by other species (ANOVA, $P<0.0001$, Tukey's HSD $P<0.05$ ).

vious observations, we did not find facultative ammonotely in hummingbirds. Although ammonia excretion was significantly higher in Archilochus alexandri than in Eugenes fulgens and Lampornis clemenciae, all three species were uricotelic. Furthermore, the fraction of nitrogen excreted as ammonia was independent of water intake. In the first section of this discussion, we compare the nitrogen requirements of hummingbirds with those of other nectar- and fruit-feeding animals and with predicted values. We examine both proximate (dietary) and ultimate (evolutionary, adaptation to diet) explanations for the low nitrogen requirements of these animals. We then discuss the apparent nitrogen retention observed in nitrogen balance studies. In the second section, we pose two nonmutually exclusive explanations for the observed patterns of ammonia excretion: differences in proportionate water loads and postrenal modification of urine among hummingbirds of different body sizes.

Because hummingbirds modulate volumetric intake to keep sugar intake relatively constant, our experimental design allowed us to manipulate nitrogen intake with minimal changes in energy consumption. Energy intake was not significantly different between dietary sucrose concentrations for any species. Archilochus alexandri, E. fulgens, and L. clemenciae maintained constant energy intake rates of 34.2, 44.5, and $57.3 \mathrm{~kJ}$ $\mathrm{d}^{-1}$, respectively. Provided with a nectar diet containing artificially high protein levels (nitrogen intake exceeded MNR by up to 11 times in A. alexandri, 6.1 times in E. fulgens, and 4.7 times in L. clemenciae) and given no other nitrogen sources (e.g., arthropods), the birds in our study varied volumetric intake based only on food energy density. Roxburgh and Pinshow (2000) report a similar observation in nectarivorous Palestine sunbirds.

\section{Nitrogen Requirements of Nectar-Feeding Birds}

The MNR and TENL of the hummingbirds examined in this study were exceptionally low and comparable to values obtained for other nectar-feeding birds (Table 1). Robbins (1993) predicted that birds should have an MNR of $430 \mathrm{mg} \mathrm{N} \mathrm{kg}{ }^{-0.75} \mathrm{~d}^{-1}$ and TENL of $270 \mathrm{mg} \mathrm{N} \mathrm{kg} \mathrm{kg}^{-0.75} \mathrm{~d}^{-1}$. Archilochus alexandri, E. fulgens, and L. clemenciae had mass-independent MNRs that were $19.9 \%, 36.7 \%$, and $28.5 \%$ of this value, respectively. The broad-tailed hummingbird (Selasphorus platycercus) had a similarly low MNR that was only $14.5 \%$ of the value predicted by Robbins for birds (McWhorter 1997). TENL values were 17\%, $28.8 \%, 23.6 \%$, and $16.7 \%$ of the predicted value for these four species of hummingbirds, respectively. Figure 6 compares predicted MNR (nitrogen balance rather than body mass balance requirements) and TENL with actual values for small (less than $100 \mathrm{~g}$ in body mass) nectar- and fruit-feeding birds, eutherian mammals, and marsupials (see Table 1 for values). The nitrogen requirements and endogenous losses of nectar-feeding animals are strikingly lower than those predicted by body mass, and these low values appear to be a general pattern that is independent of phylogenetic affinities.

Nitrogen requirements in nectar-feeding animals are probably low as a result of two interacting factors: feeding on a low nitrogen diet and physiological adaptation to that diet. When consuming liquid diets low in fiber and lipids, animals should have relatively lower fecal nitrogen losses due to low secretion of protein-digesting enzymes and bile acids, reduced sloughing of intestinal epithelial cells, and smaller populations of gut microorganisms (Robbins 1993; Roxburgh and Pinshow 2000). Indeed, metabolic fecal nitrogen (MFN) losses in nectar-feeding marsupials are among the lowest reported for mammals (Smith and Green 1987; van Tets and Hulbert 1999). There is also an evolutionary necessity to minimize nitrogen loss when specializing on low nitrogen foods (Robbins 1993). Adaptation to a nectar diet by birds may result in relatively lower rates of endogenous protein turnover and/or nitrogen recycling (facilitated in birds by mixing of urinary and fecal materials in the cloaca). In the following paragraphs, we examine these two possibilities in detail.

Endogenous urinary nitrogen (EUN) losses in nectar-feeding marsupials (Smith and Green 1987; van Tets and Hulbert 1999) and fruit-feeding bats (Delorme and Thomas 1996, 1999; Korine et al. 1996) are comparatively low. One explanation posed for the low EUN losses observed in these animals centers on the actions of glucose and insulin (Korine et al. 1996). Insulin 

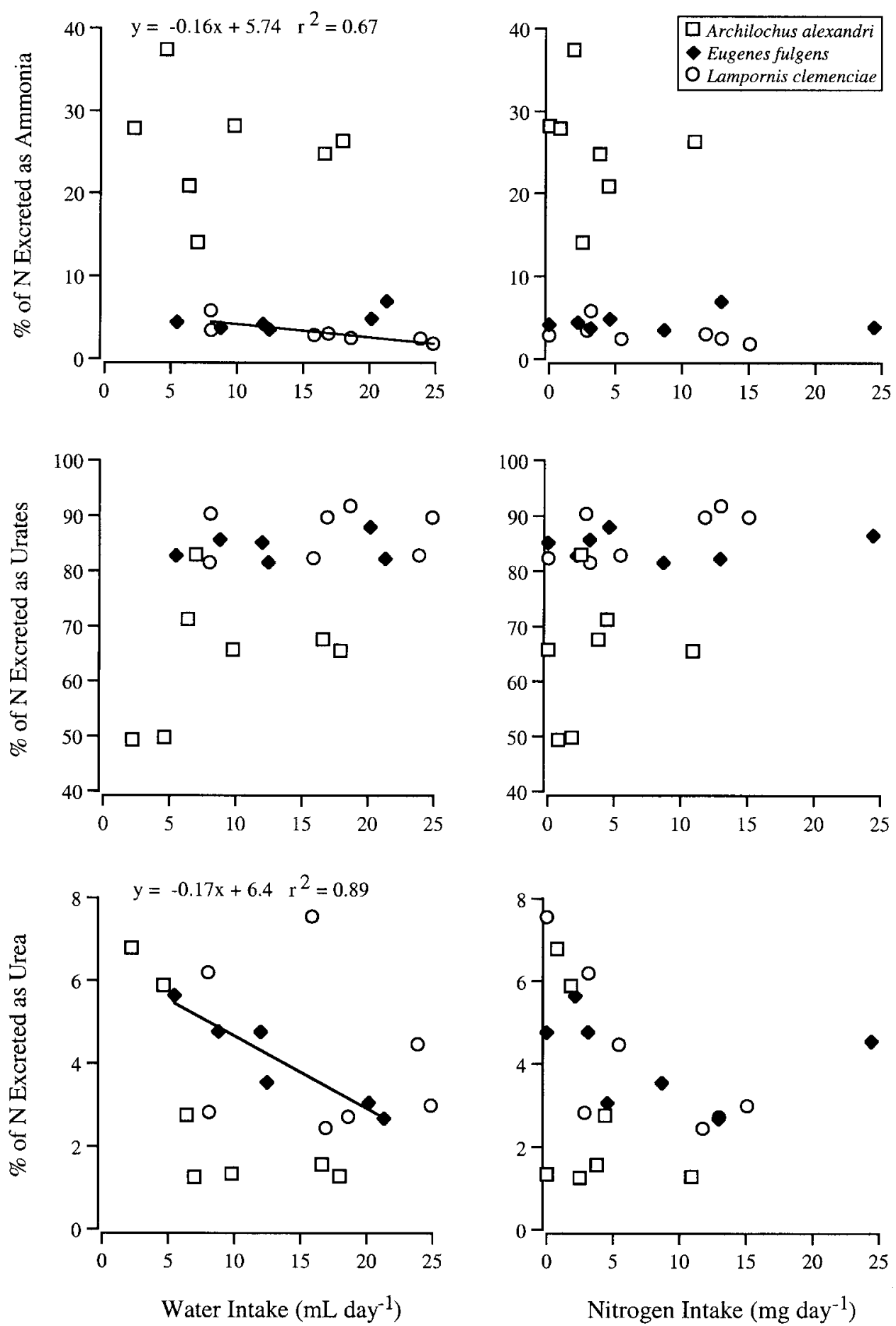

Figure 4. Proportion of assayed nitrogen excreted as ammonia did not increase with water intake rate as hypothesized in any species (Archilochus alexandri, Eugenes fulgens, Lampronis clemenciae, $n=7$ for each species). There was a significant negative correlation between ammonia excretion and water intake rate in L. clemenciae $\left(F_{1,6}=10.16, P<0.03\right)$. In addition, there was a significant negative correlation between urea excretion and water intake rate in $E$. fulgens $\left(F_{1,5}=31.79, P<0.005\right)$. There were no additional significant correlations between the proportion of nitrogen excreted in any other form and water intake rate, for any species. Creatinine excretion was positively correlated with nitrogen intake rate in A. alexandri $\left(y=0.1 x-0.004, r^{2}=0.59 ; F_{1,6}=7.15, P<0.05\right)$. There were no other significant correlations between the proportion of nitrogen excreted in any form and nitrogen intake rate, for any species. 


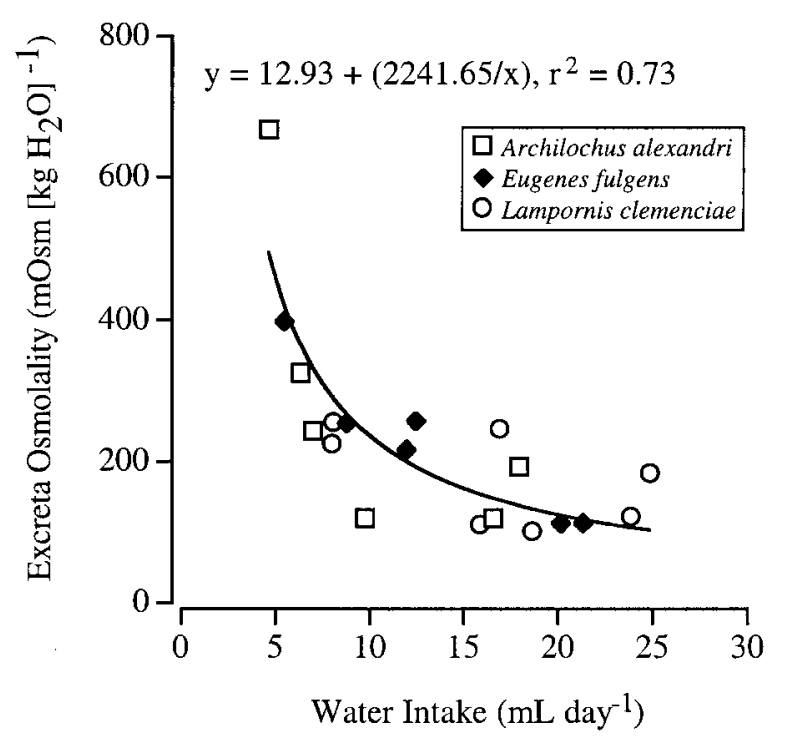

Figure 5. Excreta osmolality did not vary among species (Archilochus alexandri, Eugenes fulgens, Lampornis clemenciae, $n=7$ for each species) but decreased significantly with increasing water intake rate in a nonlinear fashion $\left(F_{1,18}=45.33, P<0.0001\right)$. Osmolality ranged from 102 to $667.8 \mathrm{mOsm}\left(\mathrm{kg} \mathrm{H}_{2} \mathrm{O}\right)^{-1}$ for all species combined.

is antigluconeogenic and therefore may minimize protein turnover by stimulating protein synthesis and decreasing protein degradation (Fukagawa et al. 1985; Florini 1987). Roxburgh and Pinshow (2000) suggest that the extremely high plasma glucose concentrations observed in nectar-feeding birds, reported for one species of sunbird and two species of hummingbirds (Beuchat and Chong 1998; Roxburgh and Pinshow 2000), may act in concert with insulin to minimize gluconeogenesis and thus contribute to very low EUN losses in these animals. The anabolic effects of insulin may not apply throughout the range of nitrogen balance, however, because protein degradation probably exceeds synthesis when nitrogen intake is zero. Mixing of fecal and urinary materials in the cloaca makes simple (i.e., nonsurgical; see, e.g., Teekell et al. 1968) separate estimates of 24-h MFN and EUN difficult to obtain in birds. It is likely that both are low in nectar-feeding birds. To disentangle the effect of diet from that of adaptation to diet, it would be instructive to measure the nitrogen requirements and endogenous losses of nonnectarivorous birds fed on a nectar diet.

The possibility of postrenal nitrogen recycling has also recently been posed to explain the low nitrogen requirements of nectar-feeding birds. Refluxing of urine into the distal large intestine, possible in birds because the ureters and intestine both open into the cloaca, is known to facilitate significant postrenal modification of urine composition (Goldstein and Braun 1986; Braun 1999; Karasawa 1999). Galliform birds have large microbial populations capable of breaking down urates in their ceca (Laverty and Skadhauge 1999), and the recycling of urates has been recently documented in chickens (Clench 1999). Ammonia resulting from the breakdown of urates may be directly absorbed, incorporated into microbial protein, or used in the enzymatic synthesis of glutamic acid, which is then absorbed by the cecal epithelium (Mortensen and Tindall 1981). Roxburgh and Pinshow (2002) found significant postrenal modification of urine in Palestine sunbirds with low water intake rates, specifically increased ammonia, and decreased urate concentrations in excreta relative to ureteral urine. They suggest that microbial nitrogen recycling may be occurring in the distal large intestine of nectar-feeding birds, which do not possess functional ceca. However, except for one unpublished observation (C. A. Beuchat, cited as personal communication in Roxburgh and Pinshow 2002), there are no data available

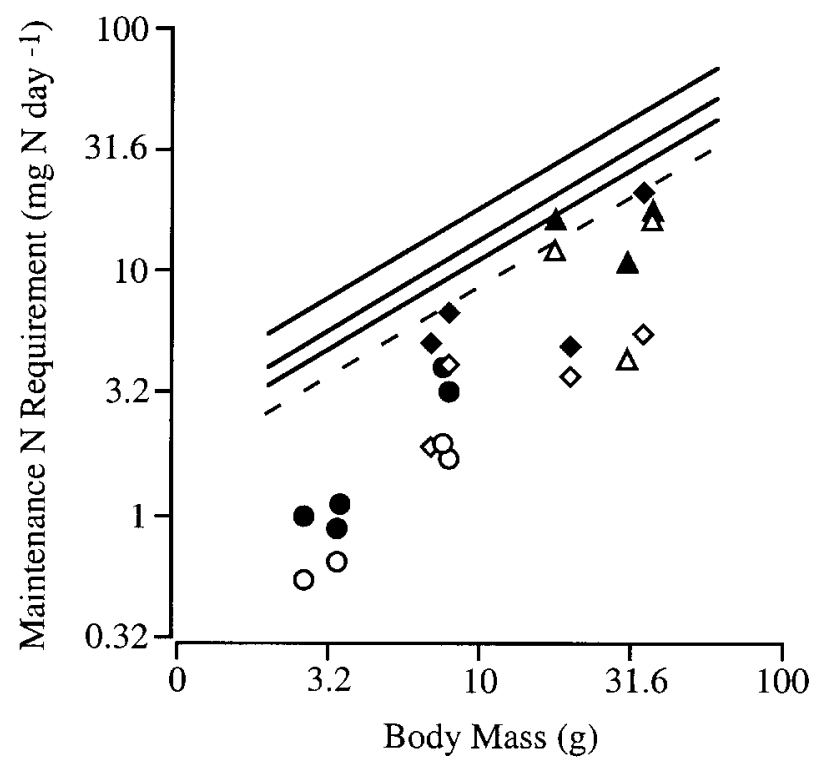

Figure 6. Maintenance nitrogen requirements (MNR; filled symbols) and total endogenous nitrogen losses (TENL; open symbols) of nectarand fruit-feeding animals are considerably lower than predicted based on body mass (circles, hummingbirds; diamonds, nectar- and fruitfeeding birds; triangles, nectar- and fruit-feeding mammals and marsupials; see Table 1 for data). Data are shown only for animals below $100 \mathrm{~g}$ in body mass. The solid lines represent MNR as a function of body mass for eutherian mammals $\left(582 \mathrm{mg} \mathrm{N} \mathrm{kg}{ }^{-0.75} \mathrm{~d}^{-1}\right)$, birds $(430$ mg N kg${ }^{-0.75} \mathrm{~d}^{-1}$ ), and marsupials (356 $\mathrm{mg} \mathrm{N} \mathrm{kg}^{-0.75} \mathrm{~d}^{-1}$ ), respectively, from the top. The dashed line represents TENL as a function of body mass for birds ( $270 \mathrm{mg} \mathrm{N} \mathrm{kg}^{-0.75} \mathrm{~d}^{-1}$ ); data are not shown for mammals and marsupials because of the difficulty of estimating metabolic fecal nitrogen losses for these animals. Allometric data are adapted from Robbins (1993). For nectar- and fruit-feeding birds only, MNR = $0.32 \times$ body mass ${ }^{1.14}, r^{2}=0.83$, TENL $=0.31 \times$ body mass $^{0.88}, r^{2}=$ 0.81 . All values in this figure were estimated by regression of apparent $\mathrm{N}$ retention on $\mathrm{N}$ intake and are not based on minimum body mass maintenance requirements. 
on the presence of bacteria with uricase activity in the gastrointestinal tracts of nectar-feeding birds. The capacity of the avian large intestine to absorb amino acids is also unknown, and evidence is inconsistent in mammals (Karasov and Hume 1997; Fuller and Reeds 1998). However, mediated absorption of glucose has been reported in the short colon or rectum of chickens (Calonge et al. 1990) and cedar waxwings (Levey and Duke 1992), at least suggesting the possibility of mediated amino acid absorption. The mechanisms and functional significance of nitrogen recycling in birds that do not possess functional ceca remain unknown (Roxburgh and Pinshow 2002).

Apparent nitrogen retention was observed in all three hummingbird species examined in this study (see Fig. 3) and has been observed in all studies of nectar- and fruit-feeding animals to date where nitrogen balance was measured (Smith and Green 1987; Brice and Grau 1991; Korine et al. 1996; Witmer 1998; Delorme and Thomas 1999; van Tets and Hulbert 1999; Roxburgh and Pinshow 2000). Similar observations of positive nitrogen balance have been made in human nutrition studies (Hegsted 1976; Young 1986). Brice and Grau (1991) found that nitrogen retention by Costa's hummingbirds (Calypte costae) increased with nitrogen intake while body mass remained constant. Birds in this study, including those on zero nitrogen diets, maintained or slightly increased body mass over the duration of the study. The slight increase in body mass observed in $A$. alexandri was probably due to increased fat mass, typically found in newly captive hummingbirds presented with ad lib. food (T. J. McWhorter and C. Martínez del Rio, unpublished data) rather than increased protein mass. The lack of a significant correlation between body mass increase and apparent nitrogen retention provides additional evidence in support of this contention. It is possible that nitrogen was actually retained by hummingbirds but more likely that it was lost as sloughed skin or feathers or as ammonia evaporated from respiratory surfaces (Brice and Grau 1991; Roxburgh and Pinshow 2000). No evidence of molt or feather growth was found in birds used in this study. Interestingly, nitrogen retention by A. alexandri was considerably lower than expected at the highest nitrogen intake level (about 11 times MNR), suggesting a nitrogen retention plateau in small hummingbirds. This result must be interpreted with caution, however, because it was only observed in one individual, and no indication of such a plateau has been observed in any other species examined (see also Hegsted 1976).

It is clear that the nitrogen requirements of nectar-feeding birds are exceptionally low. Despite these low requirements, floral nectars alone are not an adequate nitrogen source. Brice and Grau (1991) estimated that floral nectars could provide a maximum of about $14 \%$ of the nitrogen requirement of Costa's hummingbirds. Nectar-feeding birds also consume arthropods to varying degrees, depending on their nutritional needs (Wagner 1946; Paton 1982; Brice and Grau 1991; Brice 1992; van Tets and Nicolson 2000). Making the assumptions of $75 \%$ for- aging success and adequate insect abundance, they estimated that Costa's hummingbirds could meet their nitrogen requirements by foraging on insects for only $6 \mathrm{~min}^{-1}$, or about $12 \%$ of total foraging time. Time budget data for nectar-feeding birds agree very well with this estimate: male Anna's hummingbirds (Calypte anna) spent an average of $8 \mathrm{~min}^{-1}$ foraging for arthropods (Stiles 1971), New Holland honeyeaters (Phylidonyris novaehollandiae) spent $10 \mathrm{~min}^{-1}$ (only 5\% of their total foraging time; Paton 1982), and Palestine sunbirds spent 12 min $\mathrm{d}^{-1}$ (about $10 \%$ of their total foraging time; Roxburgh and Pinshow 2000).

\section{Nitrogen Excretion by Hummingbirds}

Water intake by hummingbirds in this study ranged from $83 \%$ to $665 \%$ of body mass per day for A. alexandri, $68 \%$ to $314 \%$ for E. fulgens, and $102 \%$ to $336 \%$ for L. clemenciae, with the largest mass-specific water intake rates observed in birds feeding on $0.292 \mathrm{~mol} \mathrm{~L}^{-1}$ sucrose solutions. The proportion of assayed nitrogen excreted as ammonia was significantly higher and urates significantly lower in A. alexandri than in the larger hummingbirds (Table 2). Excretion of ammonia and urates were not significantly different between E. fulgens and L. clemenciae, and the proportion of nitrogen excreted in each other form was not significantly different among species. No birds excreted $>50 \%$ of nitrogen as ammonia, or more nitrogen as ammonia than urates, during any experimental trial. Ammonia excretion was not positively correlated with water intake rate in any species. A significant negative correlation between ammonia excretion and water intake in $L$. clemenciae describes a modest decrease in the proportion of ammonia excreted from $5.8 \%$ to $1.8 \%$ with increasing water intake rate. The negative correlation between urea excretion and water intake rate in $E$. fulgens describes a similarly modest decrease from $5.6 \%$ to $2.6 \%$ of total nitrogen excreted. The excretion of all other forms of nitrogenous waste was not significantly correlated with water intake rate. Our results therefore do not support the hypothesis that hummingbirds are facultatively ammonotelic.

When food and sucrose intakes were scaled to metabolic body mass, intake by $A$. alexandri was significantly higher than that of the two larger species. We posit that mass-specific water intake $\left(\% \mathrm{Mb} \mathrm{d}^{-1}, 1.8\right.$ times greater on average in A. alexandri, which is $35 \%$ and $33 \%$ of the body mass of E. fulgens and $L$. clemenciae, respectively) explains the greater proportion of ammonia excreted by $A$. alexandri. In other words, there may be a size-dependent dichotomy of ammonia excretion in hummingbirds. Indeed, the proportion of assayed nitrogen excreted as ammonia by 3.4-g broad-tailed hummingbirds (S. platycercus) feeding on a nitrogen-free $\operatorname{diet}(31.13 \% \pm 1.66 \%, n=$ 16) was very similar to that excreted by $A$. alexandri $(25.66 \% \pm 2.71 \%)$, and again there was no positive correlation 
with water intake (T. J. McWhorter and C. Martínez del Rio, unpublished data). Basal metabolic rates of small hummingbirds such as A. alexandri are 10\%-15\% higher than predicted based on body mass (Lasiewski 1963; Prinzinger et al. 1981), whereas this is not the case for larger hummingbirds such as E. fulgens and L. clemenciae (Lasiewski and Lasiewski 1967). Higher metabolic demands necessitate higher energy intake and, as observed in A. alexandri, higher mass-specific rates of food and sucrose intake. It is possible that these small hummingbirds are reaching the lower size limit for endothermy. In order to meet their phenomenal metabolic demands they must deal with larger ingested water loads.

Postrenal modification of nitrogenous wastes may also explain the lack of a positive correlation between ammonia excretion and water intake in hummingbirds. Roxburgh and Pinshow (2002) examined the effects of water, electrolyte and protein intake, and ambient temperature on nitrogen excretion by Palestine sunbirds. They found that the proportion of ammonia in ureteral urine and excreted fluid was not correlated with ambient temperature, electrolyte intake, or water intake. Although protein intake did not influence nitrogenous wastes in ureteral urine, the proportion of ammonia in excreted fluid was higher when protein intake was reduced. This increase in excreted ammonia was accompanied by a concomitant reduction in urate concentration. The authors suggest that urate was broken down in the distal large intestine, leading to "apparent" ammonotely in sunbirds (Roxburgh and Pinshow 2002). Roxburgh and Pinshow's (2002) results question the significanci $\rightarrow$ of functional ammonotely as a feature unique to birds that experience high rates of water flux. It is possible that postrena $\rightarrow$ modification of urine in hummingbirds varies with body size. The exceptionally low MNRs of A. alexandri, C. costae, and $S$. platycercus suggest that nitrogen recycling may be occurring to a greater degree in small hummingbirds. Although there was no significant correlation of ammonia excretion and proteir $\rightarrow$ intake in any species in this study, a larger proportion of ammonia in excreta would be expected to accompany greater nitrogen recycling.

Specialization to sugary diets in birds may involve differences in the physiological mechanisms of water and protein metabolism among taxa and body sizes. It is clear that the MNR anc $\rightarrow$ TENL of nectar-feeding animals are exceptionally low. Smaller hummingbird species excrete a significantly larger proportior $\rightarrow$ of their nitrogenous wastes as ammonia than larger hummingbirds, but our results and those of van Tets et al. (2001) and Roxburgh and Pinshow (2002) do not support the hy $\rightarrow$ pothesis of facultative ammonotely with increasing water intake in birds. The physiological mechanisms that account for these differences are unknown, but differences in proportionate wate: $\rightarrow$ loads and postrenal modification of urine are strong candidates. The mechanisms of nitrogen conservation and recycling ir $\rightarrow$ birds that do not possess functional ceca remain unknown. Additional data on populations of gut microorganisms with uricase activity, the extent of postrenal modification of urine, and the protein digestive and absorptive capacities in nectarfeeding birds are necessary in order to solve this mystery.

\section{Acknowledgments}

We wish to thank Nathan Miller, Amber Hamilton, Andrea McWhorter, Theo Powers, Sean Powers, Wade Sherbrook, Emily Sherbrook, and the Southwestern Research Station staff and volunteers for capable field and lab assistance. Ana Claudia Nepote and Elena Ruiz prepared samples for elemental analysis, and Joost van Haren provided access to analytical facilities at Columbia University's Biosphere 2 Center. Berry Pinshow and Jorge Schöndube provided valuable comments on an earlier draft of this article. This research was funded by the American Museum of Natural History's Southwestern Research Station Student Support Fund, the University of Arizona Department of Ecology and Evolutionary Biology, the George Fox University Department of Biology and Chemistry, and Linfield College (fellowship to N. Miller). T.J.M. and C.M.R. were partially funded by a National Science Foundation grant to C.M.R. (IBN-0110416).

\section{Literature Cited}

Baker H.G. 1977. Non-sugar chemical constituents of nectar. Apidologie 8:349-356.

Baker H.G. and I. Baker. 1977. Intraspecific constancy of floral nectar and amino acid complements. Bot Gaz 138:183-191.

Baker I. and H.G. Baker. 1982. Some chemical constituents of floral nectars of Erythrina in relation to pollinators and systematics. Allertonia 3:25-37.

Beuchat C.A., W.A. Calder III, and E.J. Braun. 1990. The integration of osmoregulation and energy balance in hummingbirds. Physiol Zool 63:1059-1081.

$\rightarrow$ Beuchat C.A. and C.R. Chong. 1998. Hyperglycemia in hummingbirds and its consequences for hemoglobin glycation. Comp Biochem Physiol A 120:409-416.

Braun E.J. 1999. Integration of renal and gastrointestinal function. J Exp Zool 283:495-499.

Brice A.T. 1992. The essentiality of nectar and arthropods in the diet of the Anna's hummingbird (Calypte anna). Comp Biochem Physiol 101A:151-155.

Brice A.T. and C.R. Grau. 1989. Hummingbird nutrition: development of a purified diet for long-term maintenance. Zoo Biol 8:233-237.

$\rightarrow-1991$. Protein requirements of Costa's hummingbirds Calypte costae. Physiol Zool 64:611-626.

Calder W.A. III and S.M. Hiebert. 1983. Nectar feeding, diuresis, and electrolyte replacement of hummingbirds. Physiol Zool 56:325-334. 
Calonge M.L., A. Ilundáin, and J. Bolufer. 1990. Glycylsarcosine transport by epithelial cells isolated from chicken proximal cecum and rectum. Am J Physiol 258:G660-G664.

$\rightarrow$ Clench M.H. 1999. The avian cecum: update and motility review. J Exp Zool 283:441-447.

$\rightarrow$ Dawson T.J., S.K. Maloney, and E. Skadhauge. 1991. The role of the kidney in electrolyte and nitrogen excretion in a large flightless bird, the emu, during different osmotic regimes, including dehydration and nesting. J Comp Physiol B 161: 165-171.

$\rightarrow$ Delorme M. and D.W. Thomas. 1996. Nitrogen and energ, $\rightarrow$ requirements of the short-tailed fruit bat (Carollia perspicillata): fruit bats are not nitrogen constrained. J Comp Physiol B 166:427-434.

$\rightarrow-$ 1999. Comparative analysis of the digestive efficiency and nitrogen and energy requirements of the phyllostomid fruit-bat (Artibeus jamaicensis) and the pteropodid fruit bat (Rousettus aegyptiacus). J Comp Physiol B 169:123-132.

$\rightarrow$ Florini J. 1987. Hormonal control of muscle growth. Muscle Nerve 10:577-598.

$\rightarrow$ Fukagawa N., K. Minaker, J. Rowe, M. Goodman, D. Matthews $\rightarrow$ D. Bier, and V. Young. 1985. Insulin-mediated reduction of whole body protein breakdown. J Clin Investig 76:23062311.

$\rightarrow$ Fuller M.F. and P.J. Reeds. 1998. Nitrogen cycling in the gut. Annu Rev Nutr 19:385-411.

Goldstein D.L. and E.J. Braun. 1986. Lower intestinal modification of ureteral urine in hydrated house sparrows. Am , Physiol 250:R89-R95.

Goldstein D.L. and E. Skadhauge. 2000. Renal and extrarenal regulation of body fluid composition. Pp. 265-297 in G.C. Whittow, ed. Sturkie's Avian Physiology. Academic Press, San Diego, Calif.

$\rightarrow$ Gottsberger G., J. Schrauwen, and H.F. Linskens. 1984. Aminoacids and sugars in nectar, and their putative evolutionar; $\rightarrow$ significance. Plant Syst Evol 145:55-77.

Hegsted D.M. 1976. Balance studies. J Nutr 106:307-311.

$\rightarrow$ Janes D.N. and E.J. Braun. 1997. Urinary protein excretion in red jungle fowl (Gallus gallus). Comp Biochem Physiol A 118:1273-1275.

$\rightarrow$ Karasawa Y. 1999. Significant role of the nitrogen recyclin $\rightarrow$ system through the ceca occurs in protein-depleted chickens. J Exp Zool 283:418-425.

Karasov W.H. and I.D. Hume. 1997. Vertebrate gastrointestinal system. Pp. 409-480 in W. Dantzler, ed. Handbook of Comparative Physiology. American Physiological Society, Bethesda, Md.

$\rightarrow$ Karasov W.H., D. Phan, J.M. Diamond, and F.L. Carpenter $\rightarrow$ 1986. Food passage and intestinal nutrient absorption in hummingbirds. Auk 103:453-464.

King P.A. and L. Goldstein. 1985. Renal excretion of nitrogenous compounds in vertebrates. Renal Physiol 8:261-278.

$\rightarrow$ Korine C., Z. Arad, and A. Arieli. 1996. Nitrogen and energy balance of the fruit bat Rousettus aegyptiacus on natural fruit diets. Physiol Zool 69:618-634.

$\rightarrow$ Lasiewski R.C. 1963. Oxygen consumption of torpid, resting, active, and flying hummingbirds. Physiol Zool 36:122-140.

$\rightarrow$ Lasiewski R.C. and R.J. Lasiewski. 1967. Physiological responses of the blue-throated and Rivoli's hummingbirds. Auk 84:3448 .

Laverty G. and E. Skadhauge. 1999. Physiological roles and regulation of transport activities in the avian lower intestine. J Exp Zool 283:480-494.

Laverty G. and R.J. Wideman. 1989. Sodium excretion rates and renal responses to acute salt loading in the European starling. J Comp Physiol B 159:401-408.

Law B.S. 1992. The maintenance nitrogen requirements of the Queensland blossom bat (Syconycteris australis) on a sugar/ pollen diet: is nitrogen a limiting resource? Physiol Zool 65: 634-648.

$\rightarrow$ Levey D.J. and G.E. Duke. 1992. How do frugivores process fruit? gastrointestinal transit and glucose absorption in cedar waxwings (Bombycilla cedrorum). Auk 109:722-730.

López-Calleja M.V., F. Bozinovic, and C. Martínez del Rio. 1997. Effects of sugar concentration on hummingbird feeding and energy use. Comp Biochem Physiol 118A:1291-1299.

$\rightarrow$ Lotz C.N. and S.W. Nicolson. 1999. Energy and water balance in the lesser double-collared sunbird (Nectarinia chalybea) feeding on different nectar concentrations. J Comp Physiol B 169:200-206.

Martínez del Rio C. 1990. Dietary, phylogenetic, and ecological correlates of intestinal sucrase and maltase activity in birds. Physiol Zool 63:987-1011.

- 1994. Nutritional ecology of fruit-eating and flowervisiting birds and bats. Pp. 103-127 in D. Chivers and P. Langer, eds. Food and Form and Function of the Mammalian Digestive Tract. Cambridge University Press, Cambridge.

Martínez del Rio C., J.E. Schöndube, T.J. McWhorter, and L.G. Herrera. 2001. Intake responses in nectar feeding birds: digestive and metabolic causes, osmoregulatory consequences, and coevolutionary effects. Am Zool 41:902-915.

McNab B.K. 2002. The Physiological Ecology of Vertebrates: A View from Energetics. Cornell University Press, Ithaca, N.Y.

McNabb F.M.A., R.A. McNabb, and H.R. Steeves III. 1973. Renal mucoid materials in pigeons fed high and low protein diets. Auk 90:14-18.

McWhorter T.J. 1997. Energy Assimilation, Protein Balance, and Water Absorption in Broad-Tailed Hummingbirds, Selasphorus platycercus. M.S. thesis. University of Wyoming, Laramie.

McWhorter T.J. and M.V. López-Calleja. 2000. The integration of diet, physiology, and ecology of nectar-feeding birds. Rev Chil Hist Nat 73:451-460.

McWhorter T.J. and C. Martínez del Rio. 1999. Food ingestion and water turnover in hummingbirds: how much dietary water is absorbed? J Exp Biol 202:2851-2858. 
$\rightarrow$ take? Physiol Biochem Zool 73:313-324.

$\rightarrow$ Mortensen A. and A.R. Tindall. 1981. Caecal decomposition of uric acid in captive and free ranging willow ptarmigan ( $\mathrm{La}$ gopus lagopus lagopus). Acta Physiol Scand 111:129-133.

$\rightarrow$ Nicolson S.W. and P.A. Fleming. 2003. Energy balance in thi $\rightarrow$ whitebellied sunbird, Nectarinia talatala: constraints on compensatory feeding, and consumption of supplementary water. Funct Ecol 17:3-9.

$\rightarrow$ Paton D.C. 1982. The diet of the New Holland honeyeater Phylidonyris novaehollandiae. Aust J Ecol 7:279-298.

$\rightarrow$ Preest M.R. and C.A. Beuchat. 1997. Ammonia excretion by hummingbirds. Nature 386:561-562.

$\rightarrow$ Prinzinger R., K. Krüger, and K.-L. Schuchmann. 1981. Metabolism-weight relationship in 17 hummingbird specier at different temperatures during day and night. Experientia 37:1307-1309.

Robbins C.T. 1993. Wildlife Feeding and Nutrition. Academic Press, San Diego, Calif.

$\rightarrow$ Roxburgh L. and B. Pinshow. 2000. Nitrogen requirements of an Old World nectarivore, the orange-tufted sunbird Nectarinia osea. Physiol Biochem Zool 73:638-645.

. 2002. Ammonotely in a passerine nectarivore: the influence of renal and post-renal modification on nitrogenous waste product excretion. J Exp Biol 205:1735-1745.

Schmidt-Nielsen K. 1990. Animal Physiology: Adaptation and Environment. Cambridge University Press, Cambridge.

$\rightarrow$ Smith A.P. and S.W. Green. 1987. Nitrogen requirements of the sugar glider (Petaurus breviceps), an omnivorous marsupial, on a honey-pollen diet. Physiol Zool 60:82-92.
Stiles F.G. 1971. Time, energy, and territoriality of the Anna Hummingbird (Calypte anna). Science 173:818-821.

Teekell R.A., C.E. Richardson, and A.B. Watts. 1968. Dietary protein effects on urinary nitrogen components of the hen. Poul Sci 47:1260-1266.

van Tets I.G. and A.J. Hulbert. 1999. A comparison of the nitrogen requirements of the eastern pygmy possum, Cercartetus nanus, on a pollen and on a mealworm diet. Physiol Biochem Zool 72:127-137.

$\rightarrow$ van Tets I.G., C. Korine, L. Roxburgh, and B. Pinshow. 2001. Changes in the composition of the urine of yellow-vented bulbuls (Pycnonotus xanthopygos): the effects of temperature, nitrogen, and water intake. Physiol Biochem Zool 74:853857.

$\rightarrow$ van Tets I.G. and S.W. Nicolson. 2000. Pollen and the nitrogen requirements of the lesser double-collared sunbird. Auk 117: 826-830.

Wagner H.O. 1946. Food and feeding habits of Mexican hummingbirds. Wilson Bull 58:69-132.

Willmer P., G. Stone, and I. Johnston. 2000. Environmental Physiology of Animals. Blackwell Science, Oxford.

$\rightarrow$ Witmer M.C. 1998. Ecological and evolutionary implications of energy and protein requirements of avian frugivores eating sugary diets. Physiol Zool 71:599-610.

Wright P.A. 1995. Nitrogen excretion: three end products, many physiological roles. J Exp Biol 198:273-281.

Young V.R. 1986. Nutritional balance studies: indicators of human requirements or of adaptive mechanisms? J Nutr 116: 700-703. 